\title{
THE DIAGNOSIS OF VIRUS INFECTIONS
}

\author{
By D. Geraint James, M.B., M.R.C.P. \\ Senior Medical Registrar, The Middlesex Hospital, W. I
}

With the advent of specific chemotherapy, precise diagnosis is important in the efficient management of virus infections. The sulphonamides were known to be of use against the viruses of lymphogranuloma venereum (Findlay, 1940), inclusion conjunctivitis (Thygeson, 1941; 1942), and trachoma (Loe, 1938); penicillin was shown to have some effect against the' virus of psittacosis (Bedson and May, 1945; Heilman and Herrell, 1944). The development of the so-called newer antibiotics-aureomycin, terramycin and chloramphenicol-which are effective against a wider range of virus and rickettsial. infections, suggests that other as yet undiscovered substances may eventually control all diseases due to viruses and rickettsiae.

The diagnosis of some viral infections can be made at the bedside; others require close cooperation between the clinician and laboratory virologist. Each plays an important role in the management of the case, and so in the subsequent welfare of the community. The clinician, from the history, epidemiological data and clinical findings, may narrow the differential diagnosis or indeed reach the correct diagnosis. The laboratory worker may confirm the diagnosis by isolating the aetiological agent, by showing a specific immunological response, or by demonstrating characteristic pathological changes in the patient's tissues.

To improve this co-operation the clinician must know the laboratory worker's requirements in any given case; he must know which are the most appropriate specimens, the optimum stage of the disease for their collection, and the value of paired acute-phase and convalescent sera for demonstrating rising antibody titres.

\section{The Physician's Role}

(a) History.

(b) Clinical findings.

(a) History. Indications of importance in diagnosis are: the prevalence of a certain disease in the community, the seasonal incidence of certain viral infections, or a history of contact with rabid dogs, infected syringe needles (hepatitis), sheep and horses (encephalitis), mice (lymphocytic choriomeningitis) or arthropods (rickettsiae). Viral and rickettsial diseases are usually spread by direct contact, air-borne droplets, or arthropod vectors. Unlike bacterial infections, water-borne and food-borne epidemics, apart from infective hepatitis and possibly poliomyelitis, are relatively uncommon.

(b) Clinical Findings. The exanthemata are characterized by a skin eruption which appears in the prodromal or acute phase of the disease. Measles, German measles, smallpox and chickenpox, which are of viral origin, are infectious diseases of this type. Herpes simplex and herpes zoster are other examples in which eruptive skin lesions are usually characteristic.

If all viral infections had such outstanding characteristics, laboratory help would be unnecessary in diagnosis. Such is not the case, for instance, in the diagnosis of the viral pneumonias which are aetiologically distinct but clinically indistinguishable. Virus pneumonia can be caused by the viruses of influenza $A$ and $B$, psittacosis, lymphocytic choriomeningitis and the rickettsia of $\mathbf{Q}$ fever, as well as the unidentified virus (or viruses) of the so-called "primary atypical pneumonia.' In such an example the diagnosis can only be made with the help of a laboratory. Similarly, a better understanding of the various encephalitides, which are clinically indistinguishable (as are the benign aseptic meningitides), can only be obtained by recourse to the laboratory.

It is often assumed that the white blood cell count is a reliable index for differentiating viral from bacterial infections. Bacterial infections are usually accompanied by a polymorphonuclear leucocytosis, whereas viral infections are associated with a normal white cell count or perhaps a relative lymphocytosis. Occasionally, however, the white cell count is misleading. Encephalitis, lymphocytic choriomeningitis, and primary atypical pneumonia may be accompanied by a polymorphonuclear leucocytosis, whereas mild or fulminating bacterial infections may show a normal white cell count. Furthermore, associated viral and bacterial infections which occur commonly in the respiratory group make this rule-of-thumb even more misleading. Today, probably the commonest source of confusion with viral pneumonia is the inadequately treated bacterial pneumonia, in which the offending pneumococcus has been masked by small amounts of antibiotic. 
The varying clinical manifestations of the Coxsackie virus are worth stressing because they enter into the differential diagnosis of benign aseptic meningitis, non-paralytic poliomyelitis, acute pleurisy, coronary thombosis, the acute abdomen and vesicular tonsillitis. Coxsackie is a village on the banks of the Hudson River in upper New York State. During an outbreak of poliomyelitis there in 1947, Dalldorf and Sicklies isolated a virus, distinct from that of poliomyelitus. In the last three years, much interest has been focused on this virus, and the present knowledge of its relation to Bornholm disease is due to close co-operation between clinician and virologist. Its precise role as a causative agent in disease is difficult to assess. Dalldorf has rightly said that we are in the anomalous position of having discovered the cause before the disease. Such infection should be borne in mind in the diagnosis of the clinical pictures mentioned above.

\section{The Laboratory Role}

This resolves itself into (I) isolation of the virus from the patient, (2) serological tests to show immunological responses on the part of the patient and (3) the demonstration of characteristic inclusion bodies in the patient's tissues.

(I) Isolation of the Virus. This is often difficult, time-consuming or impossible. Such work, which is undertaken in special virological units, is not possible in routine hospital laboratories. The clinician, however, should know the diseases in which isolation of the virus can be undertaken conveniently, what specimens are needed and how they should be packed.

The viruses of influenza $A$ and $B$, mumps and herpes simplex are recoverable early in the disease from throat washings, saliva and vesicle fluid, respectively.

The early identification of the virus responsible for an influenzal outbreak is important, for epidemics may be transmitted by international air travel. Throat washings should be obtained as early as possible in the disease, using a broth or saline gargle. The patient should cough before gargling, so that infective bronchial material is included in the specimen. Penicillin (500 units/ $\mathrm{ml}$.) is added to suppress bacterial growth. The amnion of fertile hens' eggs is inoculated with this throat washing. If there is a delay, or for transport, the specimen should be frozen in a thermos flask packed with carbon dioxide snow. A result may be obtained in 2-4 days. The infected, amniotic fluid agglutinates chick and human erythrocytes and this haemagglutination can be inhibited by appropriate Influenza A or B specific antisera (Hirst, 1942).

A clinical diagnosis of mumps usually renders examination of saliva for virus unnecessary. The virus is recoverable from the spinal fluid in mumpso meningo-encephalitis; this has been done in patients without parotitis on the second day of $\varrho$ illness (Henle and McDougall, 1947). It is found that some cases of benign aseptic meningitis are due to the mumps virus (Kane and Enders, 1945) The best results are obtained by inoculating fertile hens' eggs as soon as possible after obtaining the fluid, but if necessary it can be frozen and kept until the results of other investigations are available. Diagnosis may be made within four to ${ }^{\infty}$ seven days, using the haemagglutination pheno- $\vec{O}$ menon mentioned above and the appropriate $\overrightarrow{-}$ immune serum.

The herpes simplex virus may affect the skino (herpes simplex, Kaposi's eczema herpeticum), muco-cutaneous junctions (herpes labialis, pro-ĩ genitalis and vulvo-vaginitis), mucous membranes (gingivo-stomatitis), eye (conjunctivitis) and cen- $\frac{\vec{\omega}}{\omega}$ tral nervous system (meningo-encephalitis). Iden- $\dot{\omega}$ tification of the virus may be of clinical importancecr in such cases. It has been isolated from moutho lesions (Dodd, et al., I939), brain (Smith, et al., I94I), spinal fluid (Armstrong, I 943), skin lesions 3 (Ruchman, et al., I947) and blood (Scott, et al., 1949). Specimens may be used directly or stored $\vec{\omega}$ in phosphate-buffered saline $\mathrm{pH} 7.2$ with $\frac{1}{2}$ perN cent. gelatine, treated with penicillin 500 units/mil: Storage during transfer should be in a carberio dioxide snow container as with other viruses. Isolation of the virus is made by inoculation of the chorio-allantoic membrane of the fertile hen's $\frac{2}{1}$ egg, inoculation of the scarified cornea of rabbits $\varrho$ or intracerebral inoculation in rabbits. A result $\overrightarrow{\vec{B}}$ may be obtained in two to seven days.

Isolation of the viruses of poliomyelitis, infective hepatitis and the Coxsackie virus can be under-? taken from specimens of faeces, but results are $\frac{0}{3}$ not available sufficiently quickly to be of diagnostic value in an individual case. They are, at 3 present, of epidemiological and research interest.

A complement-fixation test for smallpox, using $\frac{}{3}$ vesicle fluid as antigen and potent anti-vaccinial serum as antibody, may help to prove the diagnosis early in this disease. Material from several $\frac{1}{8}$ lesions should be submitted, and a result can be anticipated within 24 hours (Craigie and Wishart, N 1936; Downie, 1946).

(2) Serological tests to show an immunologicai ${ }_{N}$ response on the part of the patient are easier to $\omega$ perform, quicker, and give satisfactory results in many virus diseases. These tests are usually employed in confirming the clinical diagnosis. $\stackrel{\Phi}{\circ}$ They depend upon the demonstration of rising ${ }_{7}^{+}$ titres of specific antibodies in convalescent, as ${ }_{0}^{-}$ compared with acute-phase sera, but they suffer $\overrightarrow{\mathbb{D}}$ from the disadvantage that it is necessary to wait $\frac{?}{\mathbb{Q}}$ 
for convalescent serum. Thus the diagnosis is often retrospective, although high-acute-phase serum titres may be a helpful provisional guide.

Serological methods employed are:

(a) The in vitro complement-fixation test, using virus antigen.

(b) The in vivo animal neutralization test.

(c) The in vitro haemagglutination-inhibition test.

(d) Non-specific tests.

(a) The in vitro complement-fixation test. Potent virus antigen is titrated against serial dilutions of the patient's serum; the highest dilution of serum in which complement is fixed is the end-point. A fourfold or greater increase in titre in the convalescent, as compared with the acute-phase serum, constitutes a significant antibody response. A typical result (after Horsfall, 1950) shows:

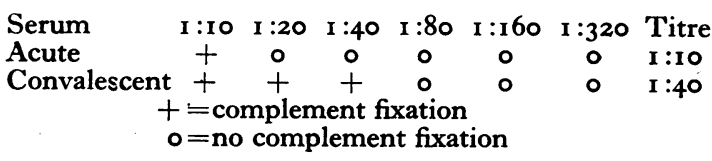

This experiment shows a two-tube, or fourfold, increase, which is significant. Such tests have the advantage that they can be performed in any laboratory where Wassermann tests are undertaken, without recourse to animal work. They are helpful in typhus (epidemic, murine and scrub); the encephalitides (distinguishing St. Louis, Japanese B and equine types); psittacosis, lymphogranuloma venereum, $Q$ fever, lymphocytic choriomeningitis, mumps, influenza $A$ and $B$, and Coxsackie infections.

(b) The in vivo Animal Neutralization Test. Animal neutralization tests depend upon the comparative powers of the patient's acute-phase and convalescent sera to neutralize the appropriate viral disease in a number of test animals. Several groups of animals are infected with the standard virus, and each group is inoculated with varying dilutions of the patient's serum. The survival rate in the varying groups is an index of the amount of antibody in the serum. This method is employed only when absolutely necessary, because of the cost and complexity of the experiment. It is impractical for routine hospital use, but remains an important research tool. For the diagnosis of some viral diseases it is essential, because the simpler in vitro complement-fixation test has not been developed.

Typical result (after Horsfall, 1950):

\begin{tabular}{|c|c|c|c|c|c|c|}
\hline $\begin{array}{l}\text { Serum } \\
\text { Acute } \\
\text { Convalescent }\end{array}$ & $\begin{array}{c}1: 10 \\
\text { S } \\
\text { S }\end{array}$ & $\begin{array}{l}\text { I :20 } \\
\text { D } \\
\text { S }\end{array}$ & $\begin{array}{l}\text { I :40 } \\
\text { D } \\
\text { S }\end{array}$ & $\begin{array}{c}\text { I :80 } \\
\text { D } \\
\text { S }\end{array}$ & $\begin{array}{l}1: 160 \\
\text { D } \\
D\end{array}$ & $\begin{array}{l}\text { Titre } \\
I: 10 \\
I: 80\end{array}$ \\
\hline & $\begin{array}{l}\text { anima } \\
\text { anim }\end{array}$ & Is surv & $\begin{array}{l}\text { viving } \\
\text { d }\end{array}$ & & & \\
\hline
\end{tabular}

There is a significant increase in titre, indicating a rise in antibody in convalescent compared with acute-phase serum.

This method is employed with the viruses of herpes simplex and yellow fever.

(c) The in vitro Haemagglutination-InhibitionTest is easy to perform, but is useful only in influenza and mumps. It depends upon the ability of the patient's serum, containing antibody, to inhibit haemagglutination by influenza and mumps virus. The patient's serum, in varying serial dilutions, is used and the highest dilution which inhibits the agglutination is taken as an end-point. There should be at least a fourfold increase in titre in the convalescent as compared with acute-phase serum. Typical result (after Horsfall, 1950):

$$
\begin{array}{rccccccc}
\text { Serum } & \text { I:10 } & 1: 20 & 1: 40 & 1: 80 & 1: 160 & 1: 320 & \text { Titre } \\
\text { Acute } & \circ & + & + & + & + & + & 1: 10 \\
\text { Convalescent } & 0 & 0 & 0 & 0 & + & + & 1: 80 \\
& 0=\text { haemagglutination inhibited } \\
+ & =\text { haemagglutination }
\end{array}
$$

The acute-phase serum has prevented haemagglutination at $\mathrm{r}: \mathrm{ro}$, whereas the convalescent serum inhibited agglutination at $\mathrm{I}: 80$. "This indicates a significant increase in titre of antibody.

With all these serological tests, it is important to remember to collect blood as early in the disease as possible, and again two or three weeks later. About $6 \mathrm{ml}$. whole blood is sufficient. This is spun in the centrifuge, and the serum stored in a refrigerator at $4^{\circ} \mathrm{C}$. until used.

(d) Non-Specific Tests. There are three diseases in which non-specific tests are useful: infectious mononucleosis, primary atypical pneumonia and typhus.

Infectious Mononucleosis. Apart from a characteristic blood count in infectious mononucleosis, the majority of cases develop heterophile antibodies which agglutinate sheep red blood cells (Paul and Bunnell, 1932; Bunnell, 1933). The test is positive in about 70 per cent. of cases by the second week of the disease, but may be positive in the first few days. Five ml. blood is collected and centrifuged to obtain the serum. Normal blood may contain sheep red cell agglutinins, which are also present in serum sickness in significant titres, and in people who have received horse serum injections. In order to avoid errors, it is well to remember the differential adsorption of these agglutinins by guinea-pig kidney and beef red blood cells (Stuart et al., 1936).

Adsorbed by

Guinea pig kidney Beef R.B.C.

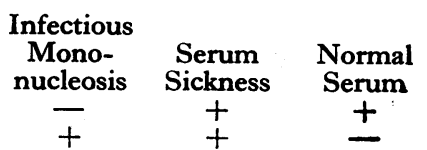


These heterophile antibodies are also present in the spinal fluid of cases of infectious mononucleosis (Silberstein et al., 1948).

Primary Atypical Pneumonia. During World War 2 several groups of workers independently observed the occurrence of cold haemagglutinins in primary atypical pneumonia (Peterson et al., 1943 ; Turner, 1943; Turner et al., 1943; Shone and Passmore, 1943). In the absence of any specific tests, this phenomenon is at present of some diagnostic help, especially when it fits in with a suggestive clinical picture. The patient's serum agglutinates human (and various animal) red blood cells at $\circ$ to $5^{\circ} \mathrm{C}$., and agglutination is absent at $37^{\circ} \mathrm{C}$. unless the titre is very high.

Cold haemagglutinins appear during the second week of the pneumonia, and decline during the first or second month after the onset. Titres should be performed at weekly intervals because a rising titre is more significant than a stationary level. Repeated examinations may show the presence of cold haemagglutinins which would otherwise remain undetected. Kneeland (r95I) has observed that they may be extremely transient, as in one case where they were absent two days before and two days after a significant titre of I: 512 .

There seems to be a rough correlation between the titre of haemagglutination and the severity of the illness; high titres being associated with a longer duration of fever (Finland et al., 1945; Laurell, 1948), and a more extensive pulmonary involvement (Jordan et al., 195I).

It is important that blood be kept warm in an incubator until centrifuged, otherwise some of the agglutinin will be lost with the patient's red cells. Five ml. blood is sufficient for the estimation. Serial dilutions of serum are titrated against a fresh 0.5 per cent. suspension of human Group $O$ red cells. Since significant titre varies with individual laboratories, it should be ascertained whether the result is expressed as the original dilution of the serum or as the /final dilution after the red cell suspension has been added.

Agglutination may be detected on the rim of the syringe when blood is taken from the patient; or it may be suspected because of difficulty in performing a blood count. This clue led to their detection by Turner in the epidemic in southern England in 1943.

About 44 per cent. of cases of primary atypical pneumonia show the phenomenon of 'streptococcus M.G. agglutination' (Horsfall, I947). This is a further non-specific test of some diagnostic value. The serum of such cases agglutinates this non-haemolytic streptococcus. Serum from $5 \mathrm{ml}$. of acute-phase and a further $5 \mathrm{ml}$. of convalescent blood is sent to the laboratory. A four- fold increase in titre is significant. This test resembles the Weil-Felix reaction, in that both depend upon the non-specific agglutination of ad bacterium by the patient's serum.

Typhus. The Weil-Felix reaction is a simples. and useful test which helps to confirm the diag nosis of epidemic, murine and scrub typhus.0 Serial dilutions of the patient's serum are mixedo with constant amounts of $B$. proteus of the OX $19, \overline{\bar{D}}$. $\mathrm{OX} 2$ and $\mathrm{OX}-\mathrm{K}$ strains. The result is expressed $\mathbb{\odot}$ as the highest dilution which causes aggregation of these test suspensions:

\begin{tabular}{|c|c|c|c|}
\hline $\begin{array}{l}\text { Epidemic typhus } \\
\text { Murine typhus } \\
\text { Scrub typhus }\end{array}$ & $\begin{array}{l}\text { OX r9 } \\
++ \\
++ \\
0\end{array}$ & $\begin{array}{c}\text { OX } 2 \\
+ \\
+ \\
0\end{array}$ & $\begin{array}{c}\text { OX-K } \\
0 \\
0 \\
++\end{array}$ \\
\hline \multicolumn{4}{|c|}{$\begin{array}{c}+=\text { agglutination } \\
\mathrm{O}=\text { no agglutination } \\
\text { (modified from Plotz, 1946) }\end{array}$} \\
\hline
\end{tabular}

The table summarizes the results obtainable ince the different varieties of typhus. It. is seen thator epidemic and murine typhus cannot be differen-은 tiated by this test. The test is of great value inepidemic and murine typhus because agglutinins 3 for OX 19 develop as early as the fifth to eighth 2 day. Results for scrub typhus become positive $\vec{e}$ in the second week, and help to confirm the N clinical diagnosis, in an endemic area, of primały eschar and a rash appearing on the fifth day fever. The test is negative in $Q$ fever.

(3) Inclusion bodies. Specific anatomical changes? in the patient's tissues are characteristic of certain virus infections. These intracytoplasmic or intranuclear inclusion bodies are found in chickenpox, smallpox, herpes zoster, herpes simplex, psittacosis and lymphogranuloma venereum, inclusion conjunctivitis and trachoma, rabies and yellow fever. At one time these bodies were of great diagnostic을 impertance, but they have now to a certain extent: been superseded by serological tests.

However, an examination of scrapings from the base of vesicles in cases of smallpox, chickenpox, herpes zoster and herpes simplex, and from the conjunctiva in trachoma and inclusion conjunc-? tivitis, may help to establish an early diagnosis. Smears in cases of chickenpox, herpes zoster and herpes simplex show identical features, which arevr characteristic but quite distinct from other vesi- $N$ cular diseases of the skin. They show greatlyN enlarged giant multinucleated epithelial cells, in which the normal chromatin granules and nucleoli $<$ are absent. The nuclei (stained with Giemsac stain) contain reddish-violet stringy amorphous $\$$ material, and green melanin granules are seen in a blue-staining cytoplasm (Blank et al., 1951). These characteristics are not seen in smallpox. Instead, smears from cases of smallpox; when 
stained by Paschen's method, show enormous numbers of elementary bodies (van Rooyen and Illingworth, 1944).

The cytoplasmic inclusion bodies of trachoma and inclusion conjunctivitis are morphologically identical, but in trachoma they are more numerous on the upper tarsal conjunctiva, whereas the reverse holds for inclusion conjunctivitis (Braley, I940).

Autopsy may reveal inclusion bodies in the liver in yellow fever, and Negri bodies in the hippocampus in rabies. the control, is an index of a positive reaction. A positive response means that the patient is, or has been at some time in his life, infected with the viruses of the psittacosis-lymphogranuloma group; it is no more specific than this, and should therefore be evaluated in the light of the clinical picture and serological results.

Skin tests have been used in mumps (Enders et al., 1945, 1946), but are unsatisfactory. They are being used in herpes simplex (Rose and Molloy, 1947) and infective hepatitis (Henle et al., r950). but their value is at present uncertain.

INCLUSION BODIES

\begin{tabular}{|c|c|c|c|c|}
\hline Disease & $\begin{array}{l}\text { Intra- } \\
\text { nuclear }\end{array}$ & $\begin{array}{l}\text { Intra- } \\
\text { cytoplasmic }\end{array}$ & Tissue in which found & Staining characters \\
\hline Chickenpox & + & Occasionally & Skin lesions & Acidophilic \\
\hline Smallpox & & + & Skin lesions & Acidophilic \\
\hline Herpes zoster & + & Occasionally & Skin lesions & Acidophilic \\
\hline Herpes simplex & + & & Skin lesions, nerve cells & Acidophilic \\
\hline Rabies & & + & Nerve cells & Acidophilic \\
\hline Yellow fever & & + & Liver cells & Acidophilic \\
\hline Psittacosis & & + & $\begin{array}{l}\text { Alveolar exudate, hilar lymph } \\
\text { glands, Kupffer cells, spleen }\end{array}$ & $\begin{array}{l}\text { Basophilic } \\
\text { Castaneda }+\end{array}$ \\
\hline Lymphogranuloma venereum & & + & Buboes & \\
\hline Inclusion conjunctivitis & & + & Conjunctiva of lower tarsus & Matrix shows posi- \\
\hline Trachoma & & + & Conjunctiva of upper tarsus & $\begin{array}{l}\text { tive glycogen } \\
\text { stain }\end{array}$ \\
\hline
\end{tabular}

\section{Skin}

Tests

Intradermal tests with virus antigen have been used in the diagnosis of individual cases, as well as in community surveys for epidemiological data. The difficulty attendant upon this method has been in preparing antigens free from impurity, which are sufficiently potent to give a specific reaction. The most popularly used is the Frei test. Frei prepared his original antigen from bubo pus in cases of lymphogranuloma venereum (Frei, 1925). It was diluted in saline and inactivated by heat. Today the most potent antigen is prepared from lymphogranuloma virus grown in the yolksac of fertile hens' eggs. The final preparation is called lygranum (Grace et al., 1940): $0.1 \mathrm{ml}$. is injected intradermally into the skin of one forearm, and a similar amount of uninfected yolk-sac suspension as control into the other. Readings are made at two and again at four days. $A$ raised inflammatory papule, at least $7 \mathrm{~mm}$. in diameter, compared with a negative response in

\section{Conclusion}

Certain points of practical value in the diagnosis of virus infections should be stressed:

(I) Specimens for virus isolation should not be sent through the post. They should be placed immediately on ice or in a thermos flask containing carbon dioxide snow, and should be taken as soon as possible to the appropriate laboratory.

(2) Virus isolation is not a routine procedure and should only be considered in suitable cases. Serological methods form the backbone of virus diagnostic procedures. Acute-phase serum should be taken as early as possible in the disease, and a second specimen two or three weeks later. Such specimens can be despatched by post.

(3) A fourfold or greater increase in titre of antibodies is significant. Such a finding should be correlated with the clinical picture in an assessment of the case.

(4) Blood for cold agglutinins should be centrifuged whilst warm, so that the patient's red cells don not precipitate any of the serum cold agglutinin. 


\begin{tabular}{|c|c|c|c|c|c|}
\hline Disease & $\begin{array}{l}\text { Virus } \\
\text { grown in }\end{array}$ & $\begin{array}{l}\text { Virus recover- } \\
\text { able from }\end{array}$ & Serological tests & Inclusion bodies in & 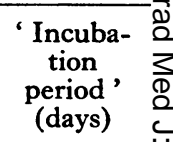 \\
\hline Mumps & $\begin{array}{l}\text { Fertile hens' } \\
\text { eggs }\end{array}$ & $\begin{array}{l}\text { Blood, saliva, } \\
\text { C.S.F. }\end{array}$ & $\begin{array}{l}\text { (a) Haemagglutination in- } \\
\text { hibition test } \\
\text { (b) Complement-fixation } \\
\text { test (C.F.T.) }\end{array}$ & - & 18 \\
\hline $\begin{array}{r}\text { Chickenpox } \\
\text { (varicella) }\end{array}$ & - & - & - & Vesicles & $12-16$ \\
\hline Smallpox (variola) & Fertile eggs & $\begin{array}{l}\text { Vesicles, pus- } \\
\text { tules }\end{array}$ & C.F.T. using vesicle fluid & Vesicles & 12 \\
\hline $\begin{array}{l}\text { German measles } \\
\text { (rubella) }\end{array}$ & Monkeys & $\begin{array}{l}\text { Blood, naso- } \\
\text { pharynx }\end{array}$ & - & - & $16-18$ \\
\hline Measles & $\begin{array}{c}\text { Monkey, } \\
\text { man }\end{array}$ & $\begin{array}{l}\text { Nasopharynx, } \\
\text { blood }\end{array}$ & - & - & II -14 \\
\hline Herpes simplex & Fertile eggs & $\begin{array}{l}\text { Vesicles, } \\
\text { saliva, } \\
\text { C.S.F. }\end{array}$ & $\begin{array}{l}\text { Animal neutralization, } \\
\text { using acute and con- } \\
\text { valescent sera }\end{array}$ & Vesicles & 3 \\
\hline Herpes zoster & 一 & 一 & 一 & Vesicles & $7-14$ \\
\hline Influenza & $\begin{array}{l}\text { Fertile eggs } \\
\text { Mice } \\
\text { Ferrets }\end{array}$ & Nasopharynx & $\begin{array}{l}\text { (a) Haemagglutination in- } \\
\text { hibition } \\
\text { (b) C.F.T. }\end{array}$ & - & $1-2$ \\
\hline Common cold & $\begin{array}{l}\text { Chimpanzee* } \\
\text { Man* } \\
\text { Fertile eggs** }\end{array}$ & Nasopharynx & - & - & Up to $\frac{8}{0}$ \\
\hline $\begin{array}{l}\text { 'Primary atypical } \\
\text { pneumonia }\end{array}$ & - & - & $\begin{array}{l}\text { (a) Cold haemagglutina- } \\
\text { tion } \\
\text { (b) Strep. M.G. }\end{array}$ & - & Up to $2 \stackrel{5}{F^{+}}$ \\
\hline$Q$ fever & Fertile eggs & $\begin{array}{l}\text { Nasopharynx, } \\
\text { blood }\end{array}$ & C.F.T. & - & 19 \\
\hline $\begin{array}{l}\text { Psittacosis } \\
\text { (ornithosis) }\end{array}$ & Fertile eggs & $\begin{array}{l}\text { Nasopharynx, } \\
\text { blood }\end{array}$ & C.F.T. & $\begin{array}{l}\text { Lungs, spleen } \\
\text { lymph glands }\end{array}$ & $4-15$ \\
\hline $\begin{array}{l}\text { Lymphogranu- } \\
\text { loma venereum }\end{array}$ & Fertile eggs & Buboes & C.F.T. & $\begin{array}{l}\text { Gland or granu- } \\
\text { loma }\end{array}$ & $3-21$ \\
\hline $\begin{array}{l}\text { Hepatitis } \\
\text { (a) Infective } \\
\text { (b) Serum } \\
\text { Infectious } \\
\text { mononucleosis }\end{array}$ & $\begin{array}{l}\text { Man } \dagger \\
\text { Fertile eggs } \dagger \dagger \\
\text { Man only } \\
-\end{array}$ & $\begin{array}{l}\text { Blood, faeces } \\
\text { Blood } \\
\text { _ }\end{array}$ & $\begin{array}{l}\text { (a) Blood picture } \\
\text { (b) Paul-Bunnell }\end{array}$ & $\begin{array}{l}- \\
-\end{array}$ & $\begin{array}{l}\text { Up to } 40 \frac{3}{3} \\
\text { Up to } 180 \frac{8}{3} \\
5-10\end{array}$ \\
\hline
\end{tabular}

\section{BIBLIOGRAPHY}

ARMSTRONG, C (1943), Pub. Health Rep., 58, 16. BEDSON, S. P., and MAY, H. B. (1945), Lancet, ii, 394. BLANK, H., BURGOON, C. F. BALDRIDGE, G. D., Ass., 146, 1410.

BRALEY, A. E. (1940), Arch. Ophthal., 24, 681.

BUNNELL, W. W. (1933), Amer. F. med. Sci., 186, 346.

CRAIGIE, J., and WISHART, F. O. (1936), Canad. Pub. Health F., 27, 371.

DALLDORF, G., and SICKLES, G. M. (1948), Science, ro8, 6 r. DOCHEZ, A. R., SHIBLEY, G. S., and MILLS, K. C. (1930), 7. exper. Med., 52, 701

DODD, K., BUDDINGH, G. J., and JOHNSTON, L. (1939), Amer. F. Dis. Child., 58, 907.

DOWNIE, A. W. (1946), Month. Bull.' Min. Health Emerg. Pub. Health Lab. Service, 5,114

DRAKE, M. E., KITTS, A. W., BLANCHARD, M. C. FARQUHAR,' J. D., STOKES,' J. Jun., and HENLE, W. (1950), 7. exper. Med., 92, 283.
ENDERS, J. F., COHEN, S., and KANE, L. W. (1945), Ibide 8I, II9. NDERS, J. F., KANE, L. W., MARIS, E. P., and STOKES, J. Jun. (1946), Ibid., 84, 341 .

FINDLAY, G. M. (1940), Brit. F. exper. Path., 21, 356.

FINLAND, M., PETERSON, O. L., ALLEN, H. E., SAMPERN B. A., and BARNES, M. W. (1945), $\mathcal{7}$. clin. Invest., 24, 458.

FREI, W. (1925), Klin. Wschr., 4, 2148.

GRACE, A. W., RAKE, G., and SHAFFER, M. F. (1940), Proqo Soc. exper. Biol. Med., 45, 259.

HEILMAN, F. R., and HERRELL, W. E. (1944), Proc. May@ Clin., I9, 204.

HENLE, G., and McDOUGALL, C. L. (1947), Proc. Soc. expero Biol. Med., 66, 209.

HENLE, G., DRAKE, M. E., HENLE, W., and STOKES, J. JunO (1950), Ibid., 73, 603 .

HENLE, W., HARRIS, S., HENLE, G., HARRIS, T. N DRẢKE,' M. E., MANGGOLD, F., and STOKES, J. Jun (1950), f. exper. Med., 92, 27 I. 


\begin{tabular}{|c|c|c|c|c|c|}
\hline Disease & $\begin{array}{l}\text { Virus } \\
\text { grown in }\end{array}$ & $\begin{array}{l}\text { Virus recover- } \\
\text { able from }\end{array}$ & Serological tests & Inclusion bodies in & $\begin{array}{l}\text { Incuba- } \\
\text { tion } \\
\text { period } \\
\text { (days) }\end{array}$ \\
\hline $\begin{array}{l}\text { Lymphocytic } \\
\text { choriomenin- } \\
\text { gitis }\end{array}$ & $\begin{array}{l}\text { Mice } \\
\text { Guinea-pigs }\end{array}$ & $\begin{array}{l}\text { Blood } \\
\text { C.S.F. }\end{array}$ & C.F.T. & - & $\begin{array}{c}\mathrm{I} \frac{1}{2}-3 \text { days } \\
\text { experi- } \\
\text { mental } \\
\text { infec- } \\
\text { t i o n } \\
\text { not } \\
\text { known } \\
\text { in } \\
\text { natural }\end{array}$ \\
\hline Poliomyelitis & Monkeys & $\begin{array}{l}\text { Faeces, naso- } \\
\text { pharynx }\end{array}$ & - & - & $4-35$ \\
\hline $\begin{array}{l}\text { Epidemic myalgia } \\
\text { (Bornholm } \\
\text { dis.) }\end{array}$ & $\begin{array}{c}\text { (a) suckling } \\
\text { mice } \\
\text { (b) adult } \\
\text { mice } \\
\text { on cor- } \\
\text { tisone }\end{array}$ & $\begin{array}{l}\text { Nasopharynx, } \\
\text { faeces }\end{array}$ & C.F.T. & - & $\begin{array}{c}\text { Probably } \\
\text { about } 5\end{array}$ \\
\hline $\begin{array}{l}\text { Encephalitis St. } \\
\text { Louis; Western } \\
\text { and Eastern } \\
\text { equine; loup- } \\
\text { ing ill) }\end{array}$ & $\begin{array}{l}\text { Mice } \\
\text { Fertile eggs }\end{array}$ & $\begin{array}{l}\text { Blood, brain, } \\
\text { C.S.F., } \\
\text { spinal cord }\end{array}$ & $\begin{array}{l}\text { (a) C.F.T. } \\
\text { (b) Animal neutralization } \\
\text { tests }\end{array}$ & - & $4-21$ \\
\hline Rabies & $\begin{array}{l}\text { Mice, rabbits } \\
\text { dogs }\end{array}$ & $\begin{array}{l}\text { Saliva, brain, } \\
\text { spinal cord }\end{array}$ & 一 & $\begin{array}{l}\text { Negri bodies in } \\
\text { hippocampus }\end{array}$ & $\begin{array}{c}\text { Io days } \\
\text { to } 7 \\
\text { months }\end{array}$ \\
\hline Typhus & $\begin{array}{l}\text { Guinea pigs, } \\
\text { Fertile eggs }\end{array}$ & Blood & $\begin{array}{l}\text { (a) Weil-Felix } \\
\text { (b) C.F.T. } \\
\text { (c) Agglutination }\end{array}$ & - & $8-18$ \\
\hline Yellow fever & $\begin{array}{l}\text { Mice, } \\
\text { monkeys }\end{array}$ & Blood & Animal neutralization & Liver & $3-6$ \\
\hline $\begin{array}{l}\text { Trachoma and } \\
\text { inclusion con- } \\
\text { junctivitis }\end{array}$ & $\begin{array}{l}\text { Man, } \\
\text { monkey }\end{array}$ & Conjunctiva & $\begin{array}{l}\text { C.F.T. using psittacosis - } \\
\text { L.G.V. antigens may } \\
\text { be positive because of } \\
\text { antigenic similarity }\end{array}$ & $\begin{array}{l}\text { Scrapings from tar- } \\
\text { sal conjunctiva }\end{array}$ & $4-12$ \\
\hline Dengue & $\begin{array}{c}\text { Man, mice, } \\
\text { fertile eggs }\end{array}$ & Blood & Mouse neutralization tests & 一 & $5-9$ \\
\hline Sandfly fever & Man & Blood & - & 一 & $2 \frac{1}{2}-6$ \\
\hline
\end{tabular}

*'Dochez et al. (1930).

**Kneeland et al. (1936).

†Drake et al. (1950).

††Henle, W., et al. (1950).

\section{BIBLIOGRAPHY}

HIRST, G. K. (1942), Ibid., 75, 49.

HORSFALL, F. L. Jun. (1947), Ann. intern. Med., 27, 275.

HORSFALL, F. L., Jun. (1950), Bull N.Y. Acad. Med., 26, 3. JORDAN, W. S., Jun., ALBRIGHT, R. W., MCCAIN, F. H., and DINGLE, J. H. (195I), Amer. $\mathcal{F}$. Med., 10, 3.

KANE, L. W., and ENDERS, J. F. (I945), F. exper. Med., 81, r 37. KNEELAND, Y., Jun. (I95I), personal communication.

KNEELAND, Y., Jun., MILLS, K. C., and DOCHEZ, A. R. (1936), Proc. Soc. exper. Biol. Med., 35, 213.

LAURELL, G. (1948), Acta. Med. Scand., 130, 299.

LOE, F. (1938), F. Amer. med. Ass., 111, 1371. PAUL, J. R., and BUNNELL, W. W. (1932), Amer. F. med. Sci.,

PETERSON, O. L., HAM, T. H., and FINLAND, M. (1943), Science, 97, 167.

PLOTZ, H. (1946), Ұ. lab. clin. Med., 31, 982.

ROSE, H. M., and MOLLOY, E. (1947), F. Immunol., 56, 287.

RUCHMAN, I., WELSH, A. L., and DODD, K. (1947), Arch. Derm. Syph., 56, 846.
SCOTT, T. F. M., CORIELL, L. L., and BLANK, H. (1949), 'Diagnosis of Viral and Rickettsial Infections,' Columbia University Press, 86.

SHONE, S., and PASSMORE, R. (1943), Lancet, ii, 445.

SILBERSTEIN, J. K., BERNSTEIN, T. C., and STERN, T. (1948), f. lab. clin. Med., 33, 1204.

SMITH, M. G., LENNETTE, E. H., and REAMES, H. R. (194I), Amer. F. Path., 17, 55.

STUART, C. A., WELCH, H., CUNNINGHAM, J., and BURGESS, A. M. (1936), Arch. intern Med., 58, 5 I 2.

THYGESON, P. (194r), Arch. Ophthal., 25, 217.

THYGESON, P., and STONE, W., Jun. (1942), F.Amer. med. Ass., $119,407$.

TURNER, J. C. (1943a), Nature, I5I, 419.

TURNER, J. C., NISNEWITZ, S., JACKSON, E. B., and BERNEY, R.'(1943), Lancet, i, 765 . VAN ROOYEN, C. E., and ILLINGWORTH, R. S. (1944), Brit. 